\title{
Telomere length in granulosa cells and leukocytes: a potential marker of female fertility? A systematic review of the literature
}

Anne-Julie Fattet ${ }^{1 \dagger}$, Simon Toupance ${ }^{2 \dagger}$, Simon N. Thornton ${ }^{2}$, Nicolas Monnin ${ }^{3}$, Jean-Louis Guéant ${ }^{4}$, Athanase Benetos ${ }^{2}$ and Isabelle Koscinski ${ }^{1,4^{*}}$ (D)

\begin{abstract}
In the context of a continuously increased delay of motherhood and of an increase of the incidence of premature ovarian failure, it is of the greatest interest to dispose of a predictive marker of the duration of the fertility window. Unfortunately, current available markers of women's fertility (hormonal rates or echography count of small follicles) have a poor predictive value of premature ovarian failure. In the last ten years, some studies have suggested that telomere length may be correlated with premature ovarian failure, but the results of these studies are contradictory. In accordance with guidelines from Preferred Reporting Items for Systematic Reviews and Meta-Analyses (PRISMA), this systematic review of the literature selected studies evaluating telomere length or telomerase activity in granulosa cells and/or in leukocytes as a premature ovarian failure marker.

Five publications (252 premature ovarian failure patients) were included in this review of experimental evidence. Two of them studied telomere length and/or telomerase activity in granulosa cells and 4 in leukocytes in women with premature ovarian failure. For each study, authors determined if there was a positive or a negative correlation between telomeric parameters and premature ovarian failure.

3 studies (178 premature ovarian failure patients) found shorter telomere length in granulosa cells and/or leukocytes and/or lower telomerase activity in premature ovarian failure patients. 2 studies (74 premature ovarian failure patients) presented contradictory results about the correlation of leucocyte telomere length with premature ovarian failure.

Shorter telomeres and diminished telomerase activity in granulosa cells appear to be associated with ovarian insufficiency. However, the number of studies and of subjects within are low and the methodology questionable. The confirmation of these results is essential with more subjects, better defined populations and more adapted methodology, in order to consider telomere length in granulosa cells and/or in leucocytes as an early and reliable marker for the decline of ovarian function.

(Continued on next page)
\end{abstract}

\footnotetext{
* Correspondence: koscinski.isa@gmail.com

${ }^{+}$Anne-Julie Fattet and Simon Toupance contributed equally to this work.

${ }^{1}$ Laboratory of Biology of Reproduction-CECOS Lorraine, University Hospital

of Nancy, 10 rue du Dr Heydenreich, 54000 Nancy, France

${ }^{4}$ Université de Lorraine, Inserm, NGERE, F-54000 Nancy, France

Full list of author information is available at the end of the article
}

(c) The Author(s). 2020 Open Access This article is licensed under a Creative Commons Attribution 4.0 International License, which permits use, sharing, adaptation, distribution and reproduction in any medium or format, as long as you give appropriate credit to the original author(s) and the source, provide a link to the Creative Commons licence, and indicate if changes were made. The images or other third party material in this article are included in the article's Creative Commons licence, unless indicated otherwise in a credit line to the material. If material is not included in the article's Creative Commons licence and your intended use is not permitted by statutory regulation or exceeds the permitted use, you will need to obtain permission directly from the copyright holder. To view a copy of this licence, visit http://creativecommons.org/licenses/by/4.0/. The Creative Commons Public Domain Dedication waiver (http://creativecommons.org/publicdomain/zero/1.0/) applies to the data made available in this article, unless otherwise stated in a credit line to the data. 
(Continued from previous page)

Keywords: Telomere length, Telomerase, Premature ovarian failure, Primary ovarian insufficiency, Premature ovarian insufficiency

\section{Background}

Over the past thirty years, in most developed countries, women are having children later and later. But, at the same time, they are also becoming more aware that their fertility declines with age. This could be the reason why many of them would be in favour of fertility preservation to ensure that they will be able, one day, to become mothers [1].

Premature Ovarian Failure (POF), first described in the 1930s, is a clinical syndrome characterized by a loss of ovarian function before the age of 40 [2] with three sequential stages called occult, biochemical and clinical [3]; corresponding to fertility decline, then an increase in Follicle Stimulating Hormone (FSH) release rate (twice), and finally oligo or amenorrhea [4] respectively. The prevalence of POF among women under 40 years of age is about $1 \%$. Furthermore, it is estimated at $1 / 1000$ for those under 30 years and 1/10,000 for those under 20 [5, 6]. About 10 to $28 \%$ of women with primary amenorrhea have POF; and in women with secondary amenorrhea, the frequency is between 4 and $18 \%$. However, prevalence varies depending on population characteristics with such factors as ethnicity. Indeed, the frequency is higher among Caucasian and African than Asian women [6]. Although the definition of POF is incomplete, the European Society of Human Reproduction and Embryology (ESHRE) working group recommends as diagnostic criteria [4]: Oligo/amenorrhea for at least 4 months and $\mathrm{FSH}>25 \mathrm{IU} / \mathrm{L}$ at twice 4 months apart.

Climacteric symptoms are less common in patients with primary amenorrhea, suggesting that they are mainly due to a cessation of estrogen excretion rather than estrogen deficiency [6].

Long-term consequences of POF are summarized in Table 1 [7]: Estrogen deficiency leads to a reduction in bone mineral density and therefore to an increased risk of osteopenia, osteoporosis and fracture with age. These patients have also an increased risk of developing

Table 1 Summary of long-term consequences of premature ovarian failure, according to [7]

\begin{tabular}{|c|c|}
\hline Cognitive dysfunction & $\begin{array}{l}\text { Memory and concentration problems, increased risk } \\
\text { of dementia }\end{array}$ \\
\hline Auto-immunity & - Increased risk of autoimmune disease, especially \\
thyroid disease
\end{tabular}


cardiovascular diseases [8] and an increased risk of allcause mortality. This pathology has also an undeniable negative impact on the psychological well-being of patients $[6,9]$. In a large majority of cases the aetiology of this pathology remains unexplained [10]. Nevertheless, in some patients with POF, genetic abnormalities [7, 1113], metabolic disorders, autoimmunity, iatrogenic, infections or environmental factors have been defined as underlying causes of this syndrome [6].

According to different authors, the discriminative value for blood FSH varies from 25 to $40 \mathrm{IU} / \mathrm{L}$.

After the diagnosis the following dosages are typically performed [14]: Anti-müllerian hormone (AMH): low; Luteinizing Hormone (LH): increased and estradiol: low, especially with a view to a treatment [15].

Currently, there is no treatment to improve ovarian function or spontaneous pregnancy rates in women with POF (between 5 and 10\% in idiopathic POF) [15] and no test or marker that predicts the risk of developing POF [4], except for the search for a few mutations known to cause this disease. As POF markers, AMH levels and antral follicle count (AFC) are partially predictive of the outcome of Assisted Reproductive Technology (ART) in patients consulting for infertility, but no predictive markers of the risk of developing a POF several years later. The only preventive measure that can be proposed to future POF patients is female fertility preservation [4] either with ovarian cortex or with oocytes and embryo cryopreservation. In addition to the cost, these different techniques of fertility preservation are not without risks to health. Therefore, it would be particularly interesting to find a predictive marker for the development of POF.

The term "telomere" derives from the Greek words "telos" which means "end", and "meros" which means "segment". Telomeres were first identified 80 years ago by Hermann Muller working with the fruit fly (Drosophila melanogaster) and by Barbara McClintock working with corn (Zea mays) cells. Telomeres are specialized non-coding double-stranded repetitive DNA-protein complexes that form protective caps at the ends of eukaryotic chromosomes [16]. These heterochromatic structures are composed of guanine rich TTAGGG repeats associated with a family of proteins known as the shelterin complex (TRF1, TRF2, POT1, TIN2, TPP1, and Rap1) [17]. These structures maintain genomic integrity through their capacity to prevent their recognition as a DNA double-stranded break and thence activation of DNA damage response (DDR), or end-toend fusions [16]. During each cell division, part of the DNA located at the chromosomes' extremity is lost due to incomplete replication of the lagging strand, a phenomenon known as the "end replication problem" [18]. In somatic cells, this leads to progressive telomere attrition/shortening and in the end to critically short telomeres, which triggers replicative senescence or apoptosis [19].

Telomerase is a ribonucleoprotein composed of a catalytic subunit called "Telomerase Reverse Transcriptase" (TERT) and an RNA matrix subunit called "Telomerase RNA component" (TERC). This RNA-dependant DNA polymerase can maintain telomere length by extending the guanine-rich single strand of telomeres, allowing DNA polymerase to achieve synthesis of the opposite strand and thus avoids the progressive loss of DNA at each replication cycle [20]. Telomerase is repressed in somatic cells but active in embryonic, stem and germ cells, as well as in $90 \%$ of tumor cells [21]. This activity prevents telomere shortening with cell division, preventing cell senescence and thus allowing extensive proliferative capacities [16].

In humans, mean telomere length ranges from 4 to 12 $\mathrm{kb}$ in somatic cells and from 10 to $20 \mathrm{~kb}$ in germinal cells $[22,23]$. These mean values differ within an individual depending on the cell type, tissues, and organs. Leukocyte telomere length (LTL), the most studied telomere length in clinical and epidemiological studies due to the easy accessibility of leukocytes, decreases with age [24]. The LTL attrition rate is higher in utero and during the first years of life and then it decreases during adulthood [25-27]. In adults, LTL attrition rates are estimated at 25 to $35 \mathrm{bp} /$ year [28]. LTL is highly heritable (60 to 70\%) and displays a wide range of mean values (4 $\mathrm{kb}$ range) between individuals of the same age in a population $[22,23,29]$. This variation is essentially determined by genetic factors through different genes, located on both autosomal and X chromosomes. However, other factors such as increased paternal age, female sex and African ancestry also contribute to TL [16].

LTL is typically shorter in men than in women, the mean difference being approximatively $200 \mathrm{bp}$ [30]. The origin of this gender gap is under debate but one of the hypotheses is that it appears at puberty due to the estrogen rise in women. Women's telomeres could be protected by the antioxidant properties of estrogens through stimulating manganese superoxide dismutase and glutathione peroxidase via Mitogen-Activated Protein kinases (MAP-kinase) and Nuclear Factor- $\kappa B$ (NF$\kappa B)$ pathways [31]. Moreover, estrogens could also directly activate telomerase via the $h T E R T$ promoter given that an estrogen-response element is present in this promoter [32]. Therefore, studying the physiological aging process through the telomere spectrum opens up a new approach to female fertility exploration [33].

\section{Rationale of systematic review of the literature}

A recent study on telomere length in germ cells suggested that this parameter could be a biomarker of germ cell and embryo quality [34]. Telomeres play also a role 
in fertility and there might exist a positive or negative association between relative TL and different factors of female and male infertility [35].

Indeed, germ cell mitotic activity is very different according to gender: male stem germ cells are constantly dividing, and the stock stays constant during the lifespan from puberty onwards. On the other hand, female germ cells stop their division before birth. On the contrary, granulosa cells must divide slowly but regularly to maintain a stock of granulosa cells around the oocytes in primordial and primary follicles from the 7th month of intra-uterine life until the menopause, and intensely during follicular maturation $[34,36]$. Therefore, in the context of female fertility, it would appear to be more interesting to investigate telomere length in granulosa cells than in germ cells. Short telomeres could impact female fertility by limiting mitosis ability of granulosa cells twice in a woman's life:

- Continually during a woman life, when granulosa cells multiply in order to maintain a pool of follicles

- Each month, when granulosa cells multiply under gonadotropins stimulation in order to develop a follicle until dominance and ovulation

Several human studies have tried to highlight a correlation between telomere length and female infertility. The following literature review evaluates the potential link between telomere length and/or telomerase activity in granulosa cells and leukocytes in women with POF.

\section{Material and methods}

A systematic review of the published literature relating to the link between telomere length and female fertility has been performed following the PRISMA guidelines (" Preferred Reporting Items for Systematic Reviews and Meta-analyses ») [37] (Fig. 1) using online search of PubMed and ScienceDirect at the date of 01/12/2019 to identify all experimental studies. The most exhaustive research was made by using the keywords: (telomere length OR telomerase) AND (primary ovarian insufficiency OR premature ovarian failure OR occult ovarian insufficiency OR hypergonadotropic ovarian failure OR premature ovarian insufficiency).

We identified 28 hits and screened the titles and/or abstracts to assess eligibility. A total of 5 publications were included in the review of experimental evidence. Two of them studied telomere length and/or telomerase activity in granulosa cells and four of them in leukocytes in women with POF.

For each study, authors determined if there was a positive or a negative correlation between telomeric parameters and premature ovarian failure.

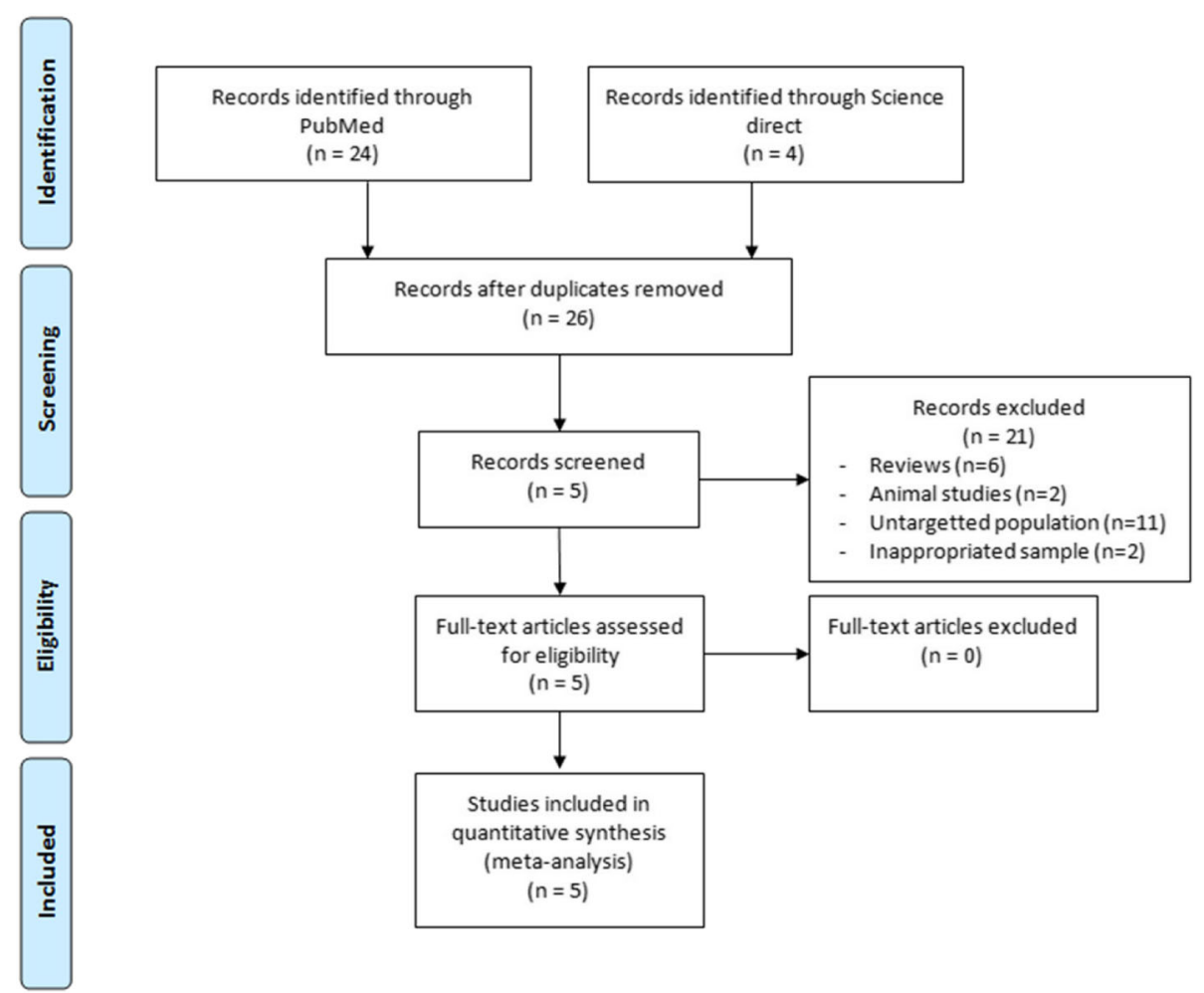

Fig. 1 PRISMA Flow diagram for identification and selection of studies 
Table 2 Characteristics of patients with biochemical POI and controls in the different studies

\begin{tabular}{|c|c|c|c|}
\hline Studies & Number & Criteria of patient's inclusion & Age \\
\hline \multirow[t]{2}{*}{ Butts et al. 2009 [38] } & $12 \mathrm{POF}$ & $\mathrm{FSH} \geq 11,4 \mathrm{IU} / \mathrm{L}$ and estradiol $\leq 293,6 \mathrm{pmol} / \mathrm{L}$ & $30-37$ \\
\hline & 42 controls & Normal FSH, tubal factor or male infertility & $23-37$ \\
\hline \multirow[t]{2}{*}{ Hanna et al. 2009 [39] } & $34 \mathrm{POF}$ & Three-month amenorrhea, FSH > $40 \mathrm{IU} / \mathrm{L}$ before the age of 40 & $21-50$ \\
\hline & 108 controls & Overall population & $17-55$ \\
\hline \multirow[t]{2}{*}{ Xu et al. 2017 [42] } & $120 \mathrm{POF}$ & Regular cycles, FSH $\geq 10 \mathrm{UI} / \mathrm{L}$, unilateral AFC $<5$ & $\leq 40$ \\
\hline & $\begin{array}{l}279 \text { control (leukocytes) } \\
90 \text { controls (granulosa) }\end{array}$ & Lack of criteria & \\
\hline \multirow[t]{2}{*}{ Miranda-Furtado et al. 2018 [40] } & $46 \mathrm{POF}$ & Amenorrhea, FSH > $40 \mathrm{UI} / \mathrm{L}$ before the age of 40 & $18-41$ \\
\hline & 75 controls & Regular cycles, FSH $<10 \mathrm{UI} / \mathrm{L}$ & \\
\hline \multirow[t]{2}{*}{ Sayban et al. 2018 [41] } & $40 \mathrm{POF}$ & Six-month amenorrhea, FSH > $40 \mathrm{UI} / \mathrm{L}$ before the age of 40 & $<40$ \\
\hline & 40 controls & Regular cycle, normal FSH & \\
\hline
\end{tabular}

Data on publication date, study objective, sample, selection criteria, number of subjects, age, methods and analysis, study outcome were extracted and resumed in the tables [38-42].

\section{Results}

Subjects

Characteristics of the 796 participants in the 5 studies and criteria dividing them into POF and control groups are presented in Table 2.

\section{Telomere length}

In the 5 studies, telomere length was assessed using a modification of the quantitative PCR method described by Cawthon [43]. After extraction, telomeric DNA was amplified by PCR in the same time as a single copy gene.

Table 3 Results for telomere length

\begin{tabular}{|c|c|c|}
\hline Studies & Samples & Results \\
\hline \multirow[t]{2}{*}{ Butts et al. 2009 [38] } & \multirow[t]{2}{*}{ Granulosa cells } & POF: $1,88 \pm 0,69^{a}$ \\
\hline & & Controls: $3,15 \pm 0,25$ \\
\hline \multirow[t]{2}{*}{ Hanna et al. 2009 [39] } & \multirow[t]{2}{*}{ Leukocytes } & POF: $9,61 \pm 1,38^{b}$ \\
\hline & & Controls: $8,98 \pm 1,15$ \\
\hline \multirow[t]{4}{*}{ Xu et al. 2017 [42] } & \multirow[t]{2}{*}{ Granulosa cells } & POF: $0,78 \pm 0,09^{c}$ \\
\hline & & Controls: $1,90 \pm 0,23$ \\
\hline & \multirow[t]{2}{*}{ Leukocytes } & POF: $0,75 \pm 0,09^{d}$ \\
\hline & & Controls: $1,79 \pm 0,12$ \\
\hline \multirow[t]{2}{*}{ Miranda-Furtado et al. 2018 [40] } & \multirow[t]{2}{*}{ Leukocytes } & POF: $0,93 \pm 0,23^{e}$ \\
\hline & & Controls: $1,07 \pm 0,27$ \\
\hline \multirow[t]{2}{*}{ Sayban et al. 2018 [41] } & \multirow[t]{2}{*}{ Leukocytes } & IOP: $0,7445^{f}$ \\
\hline & & Controls: 0,5994 \\
\hline
\end{tabular}

${ }^{a} p=0,039$

${ }^{\mathrm{b}} p=0,01$

$c_{p}<0,001$

${ }^{d} p<0,001$

${ }^{\mathrm{e}} p<0,0006$

${ }^{\mathrm{f}} p<0,05$
This technique estimates telomere length by comparing the amount of telomere repeat amplification product $(\mathrm{T})$ to the amount of the single copy gene $(\mathrm{S})$ product. The Telomere/Single Copy Gene ratio (T/S ratio) correlates with the average telomere length [38-42]. In the two studies measuring TL in granulosa cells, TL was shorter in POF patients than in controls (Table 3). The 4 studies measuring LTL reported conflicting findings. In 2 of them LTL was shorter in POF patients than in controls whereas the 2 other studies reported longer LTL in POF patients.

\section{Telomerase activity}

Telomerase activity was measured in granulosa cells in a subgroup of 123 participants in two studies (Table 2). Telomerase activity (TA) was detected using a modified telomeric repeat amplification protocol (TRAP). Presence or absence of TA was determined based on the characteristic laddering pattern of telomerase products [38] or relative TA quantified based on a standard curve [42]. In both studies, TA activity was higher in granulosa cells from controls than in those of POF patients (Table 4).

Table 5 presents the overview of the statistical results obtained in the five studies concerning TL and TA in granulosa cells and leukocytes in both POF and control groups.

\section{Discussion}

The studies of Butts et al. and of Xu et al. demonstrated that telomeres are shorter in granulosa cells (GC) of women with POF than in those of healthy controls. Moreover, these two studies observed also decreased telomerase activity in GC from POF patients. These results suggest that short telomeres in GC are associated with a fertility decrease. Therefore, telomere length in GC should be considered as a new marker of reproductive lifespan in women $[38,42]$. 
Table 4 Results for telomerase activity

\begin{tabular}{|c|c|c|c|}
\hline Authors & Expression & Results & \\
\hline \multirow[t]{2}{*}{ Butts et al. 2009 [38] } & Absence of telomerase products & POF: $11 / 12$ (92\%) & OR (95\%): $11^{\mathrm{a}}$ \\
\hline & & Controls: $21 / 42(50 \%)$ & \\
\hline \multirow[t]{2}{*}{ Xu et al. 2017 [42] } & Relative telomerase activity & POF: $1,57 \pm 0,59^{b}$ & \\
\hline & & Controls: 4,63 $\pm 0,93$ & \\
\hline
\end{tabular}

${ }^{a} p=0,02$

${ }^{\mathrm{b}} p=0,025$

The hypothesis to explain the impact of short telomeres in GC on female fertility could be through the limited proliferation capacity of cells with short TL [44]. The limited proliferation capacity of granulosa cells has been demonstrated to be a characteristic that differentiates women with POF from fertile women. The development of ovarian follicles requires an acute increase of granulosa cell number from a few cells to tens of thousands before ovulation [38]. Moreover, an insufficient activation of telomerase in early follicular development stages could accelerate telomeric attrition and severely compromise cellular functions necessary for good follicular maturation [38, 45, 46]. For many years, granulosa has been considered as containing cells with multipotent stem cell characteristics [47], as the possibility of dividing without the need of anchorage [48] and differentiation into varied cell types [49]. As other stem cells, these cells present a constitutionally high telomerase activity $[50,51]$. The pattern of this telomerase activity has been studied through the different types of follicle in ovaries and with aging, especially in bovine [52]. It has been found heterogeneous: the highest levels of telomerase activity are found in the smaller rapidly growing preantral follicles [53], followed by a decrease in activity with the maturation of the follicle [45]. This suggests that the high proliferative activity of granulosa cells could be partially linked to telomerase activity [54] and supports the hypothesis that a decrease in this activity may participate in POF. However, the obtained conclusions about telomerase activity decrease in the studies reviewed are based on analyses of luteinized granulosa cells which are terminally differentiated and morphologically distinct from proliferating granulosa cells in early stage follicles [38].

The hypothesized link between LTL and female fertility is based on the premise that LTL and GTL should be correlated. It is known that all TL are synchronized in somatic tissues at birth [55] and that despite the difference in TL observed between tissues due to different proliferative indexes, strong correlations in TL across somatic tissues subsist later in life such as in individuals with long (or short) TL in one tissue also have long (or short) TL in other tissues [56]. However, this synchrony may potentially not apply to granulosa cells since TL

Table 5 Summary table of the different studies

\begin{tabular}{|c|c|c|c|c|c|}
\hline Authors & Samples & Subjects & Setting & Method & Results \\
\hline \multirow[t]{2}{*}{ Butts et al. 2009 [38] } & Granulosa cells & $\begin{array}{l}12 \text { POF } \\
42 \text { controls }\end{array}$ & $\mathrm{TL}$ & $\mathrm{qPCR}$ & Shorter telomere in POF \\
\hline & Granulosa cells & $\begin{array}{l}12 \text { POF } \\
42 \text { controls }\end{array}$ & TA & PCR TRAPeze Telomerase Detection Kit & $\begin{array}{l}\text { Absence of TA more frequent } \\
\text { in POF }\end{array}$ \\
\hline Hanna et al. 2009 [39] & Leukocytes & $\begin{array}{l}34 \text { POF } \\
108 \text { controls }\end{array}$ & $\mathrm{TL}$ & qPCR & Longer telomere in POF \\
\hline \multirow[t]{3}{*}{ Xu et al. 2017 [42] } & Granulosa cells & $\begin{array}{l}120 \text { POF } \\
90 \text { controls }\end{array}$ & $\mathrm{TL}$ & $\mathrm{qPCR}$ & Shorter telomere in POF \\
\hline & Leukocytes & $\begin{array}{l}120 \text { POF } \\
279 \text { controls }\end{array}$ & $\mathrm{TL}$ & $\mathrm{qPCR}$ & Shorter telomere in POF \\
\hline & Granulosa cells & $\begin{array}{l}31 \text { POF } \\
38 \text { controls }\end{array}$ & TA & PCR Q-TRAP & TA level lower in POF \\
\hline Miranda-Furtado et al. 2018 [40] & Leukocytes & $\begin{array}{l}46 \text { POF } \\
75 \text { controls }\end{array}$ & $\mathrm{TL}$ & $q P C R$ & Shorter telomere in POF \\
\hline Sayban et al. 2018 [41] & Leukocytes & $\begin{array}{l}40 \text { POF } \\
40 \text { controls }\end{array}$ & $\mathrm{TL}$ & $\mathrm{qPCR}$ & Longer telomere in POF \\
\hline
\end{tabular}


dynamics of these cells are influenced by telomerase activity. The systematic review of the literature about LTL in women with POF presented contradictory results.

First, the studies of Hanna et al. and of Sayban et al. concluded that LTL was longer in women with POF. According to the authors, these results were not expected since they initially thought that women with POF would demonstrate accelerated cellular aging [39, 41]. Their first hypothesis to explain these results was that longer LTL reflected a decreased division rate in the early germ cell pool. As a consequence of fewer cell divisions in germ cells, the ovarian follicular pool was reduced, and patients had a higher risk of developing POF by consuming the oocyte pool $[39,41]$. Secondly, the authors proposed that longer telomeres in women with POF could be the result of an auto-immune mechanism which has been found frequently in this population. This autoimmune phenomenon could change the repartition of blood cells by selecting a specific cell type with longer telomeres. Nevertheless, some studies on telomere length and auto-immune disease suggest that autoimmune diseases are associated with shorter telomeres rather than with longer ones. Thus, this explanation is unlikely $[39,41]$. Finally, their third hypothesis was that long-term substitutive hormonotherapy given to these patients could slow down the telomere attrition rate by protecting telomeres from reactive oxygen species (ROS). Estrogens may increase telomerase activity by inducing hTERT expression [57]. However, the authors did not measure estrogen levels in these patients and in a study by Miranda-Furtado et al., no correlation between telomere length and estradiol levels was found. Moreover, in their study, Sayban et al. didn't mention the mean age of participants included in POF and control groups. Since LTL is highly influenced by age, this could constitute an important bias in this study [39-41].

Unlike Hanna et al. and Sayban et al., Xu et al. and Miranda-Furtado et al., reported shorter telomeres in leukocytes of women with POF than in controls [40, 42]. These results are in line with the "synchrony hypothesis" [55]. However, these 2 pilot studies were conducted with a limited number of subjects and must be confirmed with larger number of participants especially considering the contradictory results with the 2 other studies. If these results are confirmed, this would make it possible to avoid taking granulosa cells to measure GTL. If LTL has the same association with POF as GTL, it could serve as a surrogate marker with an easier accessibility and applicability in clinical and laboratory practices. However, a recent study conducted in 35 fertile egg donors did not find any association between GTL and LTL based on qPCR measurements [58].

Interestingly, it must be noted that all of these studies were conducted with a qPCR-based method to measure TL. This method is known to have high measurement error $[59,60]$ and thus requires a large sample size to offset the error, which was not the case for the 5 studies reviewed nor the one comparing GTL and LTL.

Another important bias might arise from differences in inclusion criteria between the studies reviewed. For example, level of FSH mentioned as POF criteria varied from $10 \mathrm{IU} / \mathrm{L}$ in $\mathrm{Xu}$ et al. to $40 \mathrm{IU}$ in Hanna et al., Miranda Furtado et al. and in Sayban et al. (Table 2). In Butts et al., the POF threshold was based on data from patients undergoing in vitro fertilization (IVF) with low pregnancy rate. In the $\mathrm{Xu}$ et al. study, the patients were presented with only biochemical criteria and not clinical symptoms of POF since they kept regular cycles. The literature does not highlight any direct link between FSH levels and telomere length. However, high FSH levels result from lower estradiol levels which could be linked to decreased telomerase activity [57] and compromised telomere protection against ROS. Moreover, long term hormone replacement could slow the kinetics of telomere attrition. Hanna et al. included patients from 21 to 50 years old and some of them certainly took hormonal supplementation. This may have introduced some bias. Finally, patients included presented different stages of POF which makes it difficult to compare these studies.

\section{Conclusion}

As an overall conclusion of this systematic review of the literature, shorter telomeres and diminished telomerase activity in granulosa cells appear to be associated with occult ovarian insufficiency. However, the number of studies and of subjects within are very low and the methodology questionable. If these results were to be confirmed with more subjects, better defined populations and more adapted methodology, the measurement of these parameters could be an early and reliable marker for the decline of ovarian function, as suggested in a recent reflection by Pr Barlow [61]. This may also have important consequences for women's health beyond fertility preservation. However, the question whether short telomeres observed in women with POF are a cause or a consequence of this disease remains to be addressed in future studies.

\footnotetext{
Abbreviations

POF: Premature Ovarian Failure; FSH: Follicle Stimulating Hormone; ESHRE: European Society of Human Reproduction and Embryology; AMH: Anti-Müllerian Hormone; LH: Luteinizing Hormone; AFC: Antral Follicle Count; ART: Assisted Reproductive Technology; DDR: DNA Damage Response; TERT: Telomerase Reverse Transcriptase; TERC: Telomerase RNA Component; LTL: Leukocyte telomere length; TL: Telomere Length; MAPkinase: Mitogen-Activated Protein kinases; NF-kB): Nuclear Factor- kB; hTERT: Human Telomerase Reverse Transcriptase; TA: Telomerase Activity; TRAP: Telomeric Repeat Amplification Protocol; GC: Granulosa Cells;
} 
GTL: Granulosa Telomere Length; qPCR: Quantitative Polymerase Chain Reaction

\section{Authors' contributions}

Conception, design and supervision: Isabelle Koscinski. Data collection: Anne Julie Fattet and Simon Toupance. Data analysis: Anne Julie Fattet and Nicolas Monnin. First draft of the manuscript: Anne Julie Fattet. Critical review and editing: Isabelle Koscinski, Simon Thornton, Simon Toupance, Jean Louis Guéant, Athanase Benetos. All authors read and approved the final manuscript.

\section{Funding}

This study has been supported by the French PIA project « Lorraine Université d'Excellence », reference ANR-15-IDEX-04-LUE.

\section{Availability of data and materials}

Not applicable.

Ethics approval and consent to participate

Not applicable.

\section{Consent for publication}

Not applicable.

\section{Competing interests}

The authors declare that they have no competing interest.

\section{Author details}

${ }^{1}$ Laboratory of Biology of Reproduction-CECOS Lorraine, University Hospital of Nancy, 10 rue du Dr Heydenreich, 54000 Nancy, France. ${ }^{2}$ Université de Lorraine, Inserm, DCAC, F-54000 Nancy, France. ${ }^{3}$ Centre AMP

Majorelle-Laboratory ATOUTBIO, 95, rue Ambroise Paré, 54000 Nancy, France. ${ }^{4}$ Université de Lorraine, Inserm, NGERE, F-54000 Nancy, France.

\section{Received: 24 March 2020 Accepted: 4 August 2020}

Published online: 21 August 2020

\section{References}

1. Lampic C, Svanberg AS, Karlström P, Tydén T. Fertility awareness, intentions concerning childbearing, and attitudes towards parenthood among female and male academics. Hum Reprod Oxf Engl. 2006;21(2):558-64.

2. Beck-Peccoz P, Persani L. Premature ovarian failure. Orphanet J Rare Dis. 2006;1:9.

3. Shestakova IG, Radzinsky VE, Khamoshina MB. Occult form of premature ovarian insufficiency. Gynecol Endocrinol Off J Int Soc Gynecol Endocrinol. 2016;32(suppl 2):30-2.

4. European Society for Human Reproduction and Embryology (ESHRE) Guideline Group on POI, Webber L, Davies M, Anderson R, Bartlett J, Braat $D$, et al. ESHRE guideline: management of women with premature ovarian insufficiency. Hum Reprod Oxf Engl. 2016;31(5):926-37.

5. Belaisch-Allart J, Mayenga J-M, Grefenstete I, Mokdad A, Moumin H. Premature ovarian failure: which approaches? Gynecol Obstet Fertil. 2008; 36(9):882-5

6. Rudnicka E, Kruszewska J, Klicka K, Kowalczyk J, Grymowicz M, Skórska J, et al. Premature ovarian insufficiency - aetiopathology, epidemiology, and diagnostic evaluation. Przeglad Menopauzalny. Menopause Rev. 2018;17(3):105-8,

7. Podfigurna-Stopa A, Czyzyk A, Grymowicz M, Smolarczyk R, Katulski K, Czajkowski K, et al. Premature ovarian insufficiency: the context of long-term effects. J Endocrinol Investig. 2016:39(9):983-90.

8. Roeters van Lennep JE, Heida KY, Bots ML, Hoek A, collaborators of the Dutch Multidisciplinary Guideline Development Group on Cardiovascular Risk Management after Reproductive Disorders. Cardiovascular disease risk in women with premature ovarian insufficiency: a systematic review and meta-analysis. Eur J Prev Cardiol. 2016:23(2):178-86.

9. Committee on Gynecologic Practice. Committee Opinion No. 698: hormone therapy in primary ovarian insufficiency. Obstet Gynecol. 2017;129(5):e134-41.

10. Persani $L$, Rossetti $R$, Cacciatore $C$. Genes involved in human premature ovarian failure. J Mol Endocrinol. 2010;45(5):257-79.

11. Jiao X, Ke H, Qin Y, Chen Z-J. Molecular genetics of premature ovarian insufficiency. Trends Endocrinol Metab TEM. 2018:29(11):795-807.

12. Laven JSE. Primary ovarian insufficiency. Semin Reprod Med. 2016;34(4):230-4.
13. Orlandini C, Regini C, Vellucci FL, Petraglia F, Luisi S. Genes involved in the pathogenesis of premature ovarian insufficiency. Minerva Ginecol. 2015; 67(5):421-30.

14. Broer SL, Broekmans FJM, Laven JSE, Fauser BCJM. Anti-Müllerian hormone: ovarian reserve testing and its potential clinical implications. Hum Reprod Update. 2014;20(5):688-701.

15. Committee on Gynecologic Practice. Committee opinion no. 605: primary ovarian insufficiency in adolescents and young women. Obstet Gynecol. 2014;124(1):193-7.

16. Thilagavathi J, Venkatesh S, Dada R. Telomere length in reproduction. Andrologia. 2013;45(5):289-304

17. Blackburn EH. Telomeres and telomerase: their mechanisms of action and the effects of altering their functions. FEBS Lett. 2005:579(4):859-62

18. de Lange T. Shelterin: the protein complex that shapes and safeguards human telomeres. Genes Dev. 2005:19(18):2100-10.

19. Shay JW, Wright WE, Werbin H. Defining the molecular mechanisms of human cell immortalization. Biochim Biophys Acta. 1991;1072(1):1-7.

20. Lindsey J, McGill NI, Lindsey LA, Green DK, Cooke HJ. In vivo loss of telomeric repeats with age in humans. Mutat Res. 1991;256(1):45-8.

21. Shay JW, Wright WE. Telomeres and telomerase: implications for cancer and aging. Radiat Res. 2001;155(1 Pt 2):188-93.

22. Factor-Litvak P, Susser E, Kezios K, McKeague I, Kark JD, Hoffman M, et al. Leukocyte Telomere Length in Newborns: Implications for the Role of Telomeres in Human Disease. Pediatrics. 2016;137(4):e20153927.

23. Samassekou O, Gadji M, Drouin R, Yan J. Sizing the ends: normal length of human telomeres. Ann Anat Anat Anz Off Organ Anat Ges. 2010; 192(5):284-91.

24. Baird DM, Kipling D. The extent and significance of telomere loss with age. Ann N Y Acad Sci. 2004;1019:265-8.

25. Aubert G, Baerlocher GM, Vulto I, Poon SS, Lansdorp PM. Collapse of telomere homeostasis in hematopoietic cells caused by heterozygous mutations in telomerase genes. PLoS Genet. 2012;8(5):e1002696.

26. Arias-Sosa LA. Understanding the role of telomere dynamics in Normal and dysfunctional human reproduction. Reprod Sci Thousand Oaks Calif. 2019; 26(1):6-17.

27. Benetos A, Verhulst S, Labat C, Lai T-P, Girerd N, Toupance S, et al. Telomere length tracking in children and their parents: implications for adult onset diseases. FASEB J Off Publ Fed Am Soc Exp Biol. 2019;33(12):14248-53.

28. Müezzinler A, Zaineddin AK, Brenner H. A systematic review of leukocyte telomere length and age in adults. Ageing Res Rev. 2013;12(2):509-19.

29. Hjelmborg JB, Dalgård C, Möller S, Steenstrup T, Kimura M, Christensen K, et al. The heritability of leucocyte telomere length dynamics. J Med Genet. 2015;52(5):297-302.

30. Greider CW, Blackburn EH. Identification of a specific telomere terminal transferase activity in Tetrahymena extracts. Cell. 1985;43(2 Pt 1):405-13.

31. Viña J, Borrás C, Gambini J, Sastre J, Pallardó FV. Why females live longer than males? Importance of the upregulation of longevity-associated genes by oestrogenic compounds. FEBS Lett. 2005;579(12):2541-5.

32. Bayne $\mathrm{S}$, Jones MEE, Li H, Liu J-P. Potential roles for estrogen regulation of telomerase activity in aging. Ann N Y Acad Sci. 2007;1114:48-55.

33. Benetos A, Okuda K, Lajemi M, Kimura M, Thomas F, Skurnick J, et al. Telomere length as an indicator of biological aging: the gender effect and relation with pulse pressure and pulse wave velocity. Hypertens Dallas Tex 1979. 2001;37(2 Pt 2):381-5.

34. Rocca MS, Foresta C, Ferlin A. Telomere length: lights and shadows on their role in human reproduction. Biol Reprod. 2019;100(2):305-17.

35. Vasilopoulos E, Fragkiadaki P, Kalliora C, Fragou D, Docea AO, Vakonaki E, et al. The association of female and male infertility with telomere length (Review). Int J Mol Med. 2019;44(2):375-89.

36. Ozturk S, Sozen B, Demir N. Telomere length and telomerase activity during oocyte maturation and early embryo development in mammalian species. Mol Hum Reprod. 2014;20(1):15-30.

37. Shamseer L, Moher D, Clarke M, Ghersi D, Liberati A, Petticrew M, et al. Preferred reporting items for systematic review and meta-analysis protocols (PRISMA-P) 2015: elaboration and explanation. BMJ. 2015;350:97647.

38. Butts S, Riethman H, Ratcliffe S, Shaunik A, Coutifaris C, Barnhart K. Correlation of telomere length and telomerase activity with occult ovarian insufficiency. J Clin Endocrinol Metab. 2009;94(12):4835-43.

39. Hanna CW, Bretherick KL, Gair JL, Fluker MR, Stephenson MD, Robinson WP. Telomere length and reproductive aging. Hum Reprod Oxf Engl. 2009;24(5): $1206-11$. 
40. Miranda-Furtado CL, Luchiari HR, Chielli Pedroso DC, Kogure GS, Caetano LC, Santana BA, et al. Skewed X-chromosome inactivation and shorter telomeres associate with idiopathic premature ovarian insufficiency. Fertil Steril. 2018;110(3):476-85 e1.

41. Sayban S, Mirfakhraie R, Omrani MD, Ghaedi H, Heidary H, Yaghoobi H, et al. Idiopathic premature ovarian failure and its association to the abnormal longitudinal changes of telomere length in a population of Iranian infertile women: a pilot study. Meta Gene. 2018;18:58-61.

42. Xu X, Chen X, Zhang X, Liu Y, Wang Z, Wang P, et al. Impaired telomere length and telomerase activity in peripheral blood leukocytes and granulosa cells in patients with biochemical primary ovarian insufficiency. Hum Reprod Oxf Engl. 2017;32(1):201-7.

43. Cawthon RM. Telomere measurement by quantitative PCR. Nucleic Acids Res. 2002;30(10):e47.

44. Liu CC, Ma DL, Yan T-D, Fan X, Poon Z, Poon L-F, et al. Distinct responses of stem cells to telomere uncapping-a potential strategy to improve the safety of cell therapy. Stem Cells Dayt Ohio. 2016;34(10):2471-84.

45. Kosebent EG, Uysal F, Ozturk S. Telomere length and telomerase activity during folliculogenesis in mammals. J Reprod Dev. 2018;64(6):477-84.

46. Kinugawa C, Murakami T, Okamura K, Yajima A. Telomerase activity in normal ovaries and premature ovarian failure. Tohoku J Exp Med. 2000; 190(3):231-8.

47. Kossowska-Tomaszczuk K, De Geyter C. Cells with stem cell characteristics in somatic compartments of the ovary. Biomed Res Int. 2013;2013:1-8.

48. Lavranos TC. Anchorage-independent culture of bovine Granulosa cells: the effects of basic fibroblast growth Factor and Dibutyryl cAMP on cell division and differentiation. Exp Cell Res. 1994;211(2):245-51.

49. Kossowska-Tomaszczuk K, Geyter CD, Geyter MD, Martin I, Holzgreve W, Scherberich A, et al. The multipotency of luteinizing Granulosa cells collected from mature ovarian follicles. Stem Cells. 2009;27(1):210-9.

50. Roake CM, Artandi SE. Regulation of human telomerase in homeostasis and disease. Nat Rev Mol Cell Biol. 2020;21(7):384-97.

51. Slack JMW. What is a stem cell? WIREs Dev Biol. 2018;7(5):e323.

52. Goto H, Iwata H, Takeo S, Nisinosono K, Murakami S, Monji Y, et al. Effect of bovine age on the proliferative activity, global DNA methylation, relative telomere length and telomerase activity of granulosa cells. Zygote Camb Engl. 2013;21(3):256-64.

53. Lavranos TC, Mathis J, Latham S, Kalionis B, Shay J, Rodgers R. Evidence for ovarian Granulosa stem cells: telomerase activity and localization of the telomerase ribonucleic acid component in bovine ovarian follicles. Biol Reprod. 1999;61:358-66.

54. Liu J-P, Li H. Telomerase in the ovary. Reprod Camb Engl. 2010;140(2):215-22.

55. Youngren $\mathrm{K}$, Jeanclos E, Aviv H, Kimura M, Stock J, Hanna M, et al. Synchrony in telomere length of the human fetus. Hum Genet. 1998;102(6): 640-3.

56. Daniali L, Benetos A, Susser E, Kark JD, Labat C, Kimura M, et al. Telomeres shorten at equivalent rates in somatic tissues of adults. Nat Commun. 2013; 4:1597.

57. Grasselli A, Nanni S, Colussi C, Aiello A, Benvenuti V, Ragone G, et al. Estrogen receptor-a and endothelial nitric oxide synthase nuclear complex regulates transcription of human telomerase. Circ Res. 2008;103(1):34-42.

58. Lara-Molina EE, Franasiak JM, Marin D, Tao X, Díaz-Gimeno P, Florensa M, et al. Cumulus cells have longer telomeres than leukocytes in reproductiveage women. Fertil Steril. 2020;113(1):217-23.

59. Aviv A, Hunt SC, Lin J, Cao X, Kimura M, Blackburn E. Impartial comparative analysis of measurement of leukocyte telomere length/DNA content by southern blots and qPCR. Nucleic Acids Res. 2011;39(20):e134.

60. Nettle D, Seeker L, Nussey D, Froy H, Bateson M. Consequences of measurement error in QPCR telomere data: a simulation study. PLoS One. 2019;14(5):e0216118.

61. Barlow DH. Telomere length and its assessment for female reproduction. Fertil Steril. 2020;113(1):91-2.

\section{Publisher's Note}

Springer Nature remains neutral with regard to jurisdictional claims in published maps and institutional affiliations.

\section{Ready to submit your research? Choose BMC and benefit from}

- fast, convenient online submission

- thorough peer review by experienced researchers in your field

- rapid publication on acceptance

- support for research data, including large and complex data types

- gold Open Access which fosters wider collaboration and increased citations

- maximum visibility for your research: over $100 \mathrm{M}$ website views per year

At BMC, research is always in progress.

Learn more biomedcentral.com/submissions 